\title{
The Manchester Driver Behaviour Questionnaire as a Predictor of Road Traffic Accidents
}

\author{
A.E. af Wåhlberg* (a) \\ L. Dorn (b) \\ and \\ T. Kline (c) \\ a. Department of Psychology \\ Uppsala University \\ Uppsala, Sweden \\ b. Department of Systems Engineering and Human Factors, \\ Cranfield University \\ Cranfield, United Kingdom \\ c. University of Calgary \\ Calgary, Canada
}

Received: 14 February 2008

* e-mail: anders.af_wahlberg@psyk.uu.se

Homepage: http://www.psyk.uu.se/hemsidor/busdriver 


\begin{abstract}
The Driver Behaviour Questionnaire (DBQ) has mainly been used as predictor of selfreported road traffic accidents. The associations between crashes and the violation and error factors of the DBQ however, may be spuriously high due to reporting bias. In the present study, the DBQ was tested as predictor of self-reported and recorded accidents in four samples of private and professional drivers. The findings show that the DBQ scale only predicts self-reported accidents, not recorded crashes, despite the higher validity of company data, and the higher means of the recorded data across these samples. The results can be explained by a common method variance bias. In our review of the DBQ research, the use of the instrument was found to be heterogeneous concerning the number of items, scales used, and factor analytic methods applied. Thus, the DBQ may not be as homogenous and as successful in predicting accidents as is often claimed.
\end{abstract}

Keywords: DBQ, questionnaire, traffic accident, crash, driver, common method variance 


\section{Introduction}

Road traffic accidents are a major health and economical problem throughout the world, and research within traffic psychology has largely centered on this problem. One of the main approaches has been the use of individual differences to predict their later accident involvement (for reviews, see Signori \& Bowman, 1974; McGuire, 1976; Golding, 1983; Hansen, 1988; Lester, 1991; Arthur, Barrett \& Alexander, 1991; Elander, West \& French, 1993; Peck, 1993; af Wåhlberg, 2003). If this could be done with an acceptable degree of accuracy, it would be possible to identify drivers for training or other interventions. However, for practical use, the measurement technique must be valid and easy to use on a large scale.

The simplest way of measuring behaviour is to ask people how they typically behave, effectively using individuals as their own monitoring devices. In this way, any behaviour, thought, attitude and experience can, in principle, be canvassed very cheaply, for any time period. Other methods, which have been tried for traffic accident prediction, do not share these advantages. Medical examinations, for example, are mainly about the current somatic state of the individual (unless supplemented with self-reports or archive data). Objective driving behaviour measurements are similarly restricted to the, usually very short, period of data gathering.

Possibly due to these factors, driver behaviour questionnaires have been very popular for many decades within traffic research. However, few of the many suggested variants have reached wider acceptance. On the contrary, many inventories seem to have been constructed specifically for a single study, or possibly used a few times by a research group. This would seem to be the case for the Driving Behavior 
Questionnaire (Arthur, Strong \& Williams, 1994), the Driving Habits Questionnaire (Schwebel, Severson, Ball \& Rizzo, in press), the Driving Behavior Rating Scale (Barkley, Murphy, Du Paul \& Bush, 2002), the Driving History Survey (Knouse, Bagwell, Barkley \& Murphy, 2005) as well as a number of others without specific names (e.g. Gumpper \& Smith, 1968; McGuire, 1972; Smith \& Kirkham, 1982; Larson \& Merritt, 1991; Chou, Miyazaki \& Maruyama, 1994).

However, the Manchester Driver Behaviour Questionnaire (DBQ) (Reason, Manstead, Stradling, Baxter \& Campbell, 1990) has gained wide acceptance (e.g. Blockey \& Hartley, 1995; Parker, Reason, Manstead \& Stradling, 1995; Rimmö \& Åberg, 1999; Westerman \& Haigney, 2000; Sullman, Meadows \& Pajo, 2002). So far, at least fifty-four published studies have used at least parts of this instrument in various ways (list available upon request from first author). The DBQ has its origins in Reason's error theory (Reason, 1987; Reason, Manstead, Stradling, Baxter \& Campbell, 1990) and measures what is called aberrant driving behaviours (errors ${ }^{1}$, lapses and violations). One of its basic intended uses is the prediction of (individual differences in) traffic accidents. Although a number of studies have tested this (thirtyone of the above-mentioned fifty-four), and reported some success, there is one feature about the DBQ reports that should be noted; they have almost exclusively used self-reported accidents as the dependent variable. The only known exception in the use of recorded accidents (Caird \& Kline, 2004) found no significant effects.

This is notable because self-reports of traffic accidents have repeatedly been shown to have dubious validity (e.g. Arthur, 1991; Szlyk, Seiple \& Viana, 1995; McGwin, Owsley \& Ball, 1998) due to memory loss (Maycock, Lockwood \& Lester, 1991; Maycock \& Lester, 1995; Chapman \& Underwood, 2000) and possibly other

\footnotetext{
${ }^{1}$ The terminology has changed somewhat; other terms used include mistakes, slips, aggressive violations etc.
} 
biases, like over-reporting (af Wåhlberg, 2002a) and selective under-reporting (Brown \& Beardie, 1960). Furthermore, archival sources of accidents (state and company records) seem to have different associations, as compared to self-reported ones, with various predictors (e.g. Owsley et al, 1991; Arthur et al, 2001; af Wåhlberg, 2002a). Given that the DBQ uses self-reports to predict other self-reports, it is likely that at least some part of the significant associations reported between one or two of the factors and accidents is due to the problem of common method variance (Podsakoff, MacKenzie, Lee \& Podsakoff, 2003). Common method variance refers to (in part) people's tendency to want to respond consistently across related measures. In other words, they demonstrate a tendency to locate their responses in particular regions of a scale such as at one end, or the middle. When these responses are analysed they tend to create a correlation that is artificially inflated. Although the widespread existence of this problem has been questioned, even a critic such as Spector (2006) acknowledges that there are many situations where this type of problem might occur. Other researchers have shown effects that can be traced to common methods of gathering data within studies (e.g. Williams, Cote \& Buckley, 1989; Moorman \& Podsakoff, 1992).

With regards to traffic psychology, it could be that people report in a self-congruent manner about their accidents and behaviours, when the latter are perceived as relevant for traffic safety. This mechanism is a slight extension of the 'consistency motif' suggested for cognitions and attitudes (Osgood \& Tannenbaum, 1955), in which respondents search for similarities between items and respond in ways that are more consistent than is actually the case in real life. For traffic behaviour and its link with accidents, it could be that there is an artifactual consistency in reporting between the number of accidents respondents have been 
involved in and the behaviours they believe may have had an impact on their accident record. If this hypothesis is applied to the $\mathrm{DBQ}$, it can, for example, be predicted that associations between these factors and accidents will be stronger if the accidents are self-reported, than if they are retrieved from actual records.

The present study was undertaken to test the specific hypothesis that the DBQ can predict self-reported accidents, but not recorded crashes. The two main sources for objective accident data are state records and transport company data. There are two methodological problems that emanate from this hypothesis. First, state records typically have lower means (and variability) than self-reported accident data for the same drivers over short time periods (Schuster \& Guilford, 1962; McGuire, 1973; Sobel \& Underhill, 1976), and any comparison of predictive power between these sources is therefore automatically confounded by this difference. However, for the present study, it was possible to use self-reported and transportation company data. Although the evidence regarding the validity of such data is sparse, it has been shown for one of the companies used here that the records contain more accidents than the drivers themselves reported for a three-year period (af Wåhlberg, 2002a).

The second problem to consider is that the DBQ was not developed for bus drivers or other professional driver groups, and it could be argued that the DBQ is not applicable for such samples. However, it is possible to adapt the DBQ for bus driving, deleting items that are not suitable (car specific), and replacing them with similar ones that are pertinent to bus driving. If the general principle of aberrant driving behaviour predicting accident involvement is robust, then the DBQ should withstand minor alterations to the surface content of some items and still be able to predict accidents. It should also be remembered that a few studies have made these kinds of alterations for specific populations other than normal car drivers (e.g. older 
people (Parker, 1999), truck drivers (Sullman, Meadows \& Pajo, 2002) and various other professional drivers (Sümer, 2003)), yet managed to predict their self-reported accident involvement.

Turning to accidents as a dependent variable, this is an area fraught with difficulties, both statistical and methodological. The basic problem is the uncommonness of traffic incidents of such severity as to be called accidents, which creates a skewed distribution in most populations for the time periods used for calculations. This means that statistical power will be low, and the range of suitable methods somewhat restricted. At the same time, it should be remembered that many different statistical analyses have been used by various researchers, and there is some virtue in using certain tests even when they have sub-optimal power, given the importance of being able to compare results.

One methodological problem of some importance in the present study concerns what kind of accidents should be used as the dependent variable. Most researchers take all accident data recorded, without further consideration (af Wåhlberg, 2003), while some deliberate over culpability, responsibility, activepassive and similar concepts. The differences between the first two terms (and several other, such as 'avoidable') would seem to be slight, although it is most often hard to know exactly what is meant by any of these terms, as they have seldom been defined (af Wåhlberg, 2003). They all concern whether a driver has been partly responsible for the cause of an accident, and mainly seem to differ in their degree of severity of their criterion; the percentage of collisions that are ascribed as at least partly a driver's fault differ rather strongly between studies (from 35 percent (Brandaleone \& Flamm, 1955) to 85 percent (Drummer et al, 2004)). The active-passive notion (West, 1997), however, is different from the various culpability terms, and mainly concerns which 
party was moving faster before the collision. Exactly what active-passive means is hard to determine (af Wåhlberg, 2002b), but there is probably a good degree of overlap with between this term and culpability. The problem is whether there is such a thing as an accident involvement that is unrelated to the driver's behaviour. This is a daunting issue that has so far not been resolved. It is not the purpose of this study, however, to resolve this issue, merely to bring it to the reader's attention.

The originators of the DBQ did not state explicitly which factors may relate to the concept of culpability, but the notion of active/passive accidents has at times been used in DBQ studies (e.g. Parker, McDonald, Rabbitt \& Sutcliffe, 2000; Fergusson, Horwood \& Boden, in press). As the whole concept of aberrant driving would seem to imply that the drivers with these behaviours cause accidents, it would be reasonable to assume that only culpable accidents should be included as the dependent variable. Yet most DBQ studies have not considered, or even discussed the issue. For the present study then, different variants of the dependent variable were used to address this methodological problem.

Summing up, the present study compared the predictive power of the DBQ using traffic accidents from different sources as dependent variables, with the main consideration being self-reported versus recorded ones. To make the results interpretable and comparable across samples, several statistical methods were employed, as well as different accident variables.

\section{Method}

\section{General}

Data from four different research projects were analyzed in this study. The first was undertaken in the United States, the second in the United Kingdom, the third in Sweden, and the fourth in Canada. For the first two samples, a DBQ for car drivers 
was distributed, in the third, respondents completed a DBQ modified for bus driving, and in the fourth a DBQ for professional truck drivers was used. Each study had its own unique combination of sample, materials and dependent variables, but all contributed a facet concerning the use of self-reported accidents and the administration of the DBQ. Descriptive data for the four samples are shown in Table 1.

\section{Questionnaires}

The DBQ exists in many different versions, where each researcher, or even study, seems to have used a unique combination of number and type of items (see further information in the discussion). In the present report, the original 50-item version was used (Reason, Manstead, Stradling, Baxter \& Campbell, 1990; Blockey \& Hartley, 1995) in the U.S. and U.K. studies (see Appendices 1 and 2), but with a six-point Likert-type response scale instead of the original five (see further information in the results section). The U.S. study DBQ also had a code for 'Not applicable'.

The Swedish Bus-DBQ questionnaire administered for the present study consisted of thirty-two items with a six-point Likert-type response scale (see Appendix 1), where fourteen were newly created to be bus driver specific, and the others were taken from the Swedish version of the DBQ (Åberg \& Rimmö, 1998; Rimmö \& Åberg, 1999). The aim was to include similar numbers of violations, errors, slips and lapses (see comments in Appendix 3).

In the Canadian sample, 15 items from the DBQ (Parker, Reason, Manstead \& Stradling, 1995) and an additional item on using cellular phones were used to assess general driving errors and violations (see Appendix 4). The items were responded to on a five-point Likert-type scale.

\section{Samples and procedures}


The U.S. sample consisted of older adults without diagnosis of dementia, Parkinson's disease, psychosis, eye conditions other than refractive error or cataract, or any illness, enrolled in a prospective study on the impact of cataracts on mobility (ICOM) as described in (Owsley et al., 2002; Owsley, Stalvey, Wells, \& Sloane, 1999; Owsley, Stalvey, Wells, Sloane, \& McGwin, 2001). All were licensed to drive in Alabama and were active drivers. Drivers had been recruited through eye care clinics in the Birmingham, Alabama area. The questionnaire was distributed at the third annual follow-up visit for the ICOM study. They were asked to complete the DBQ using the reference of their behaviours over the past 10 years.

All U.K. drivers were employees of a major U.K. bus company. Two hundred and forty-eight drivers returned the questionnaire, but ten of them had to be discarded due to missing data, and the final sample consisted of 238 respondents. The questionnaire contained items about name and payroll number, so all respondents could be identified.

In Sweden, the Bus-DBQ and a pre-paid envelope were distributed to about 350 drivers $^{2}$ at the bus company Gamla Uppsalabuss (GUB) through their personal mailboxes at the bus garage. Each questionnaire was marked with the driver's employment number for identification purposes. A reward consisting of a free ticket to the movies was sent to each respondent. After three weeks, a reminder was sent to drivers that had not responded. Finally, a few drivers were contacted in person and asked to complete the questionnaire. A total of 127 questionnaires were returned with complete data for the analyses undertaken here (a somewhat larger number was used for factor analysis and some accident calculations using all available data).

\footnotetext{
${ }^{2}$ A higher number of questionnaires were distributed to mail slots, but several of these were probably vacant, due to the employment numbers not having been updated on slots of drivers who had quit or were on long-term sick leave.
} 
In Canada, all participants were professional drivers for a single oil and gas distribution company. Surveys were distributed to drivers through a company contact during January and February of 1998. To ensure confidentiality of the data collection procedure, surveys were sent directly to the researchers. A total of 330 surveys were distributed and 190 of them were returned (58\% response rate).

However, only 115 cases had complete data for all variables used in the present study. These data were used in Caird and Kline (2004), but the present analysis was more extensive.

Table 1 about here

\section{Accident data}

Questions concerning the number of traffic accidents the driver had been involved in during the last year and how many of these instances the police had been called to scene were included in the U.S. DBQ study, while recorded accident data was supplied by the Alabama Department of Public Safety for a period of ten years (before and after the collection of the self-report data). The recorded accident data included information about culpability for each crash, assigned by the reporting police officer. In a few cases (nine), culpability had not been recorded. These cases were treated as culpable accidents, as it was more probable that some blame could have been allotted, than no blame given the findings of af Wåhlberg and Dorn (2007). Therefore, four different dependent variables were available for this sample, two self-reported (number of crashes and number of police attended crashes) and two recorded 
(culpable and All) with the latter variables differing as to culpability, while the first two variables probably measured different degrees of crash severity.

A major British bus company supplied recorded traffic accident data for the U.K. study. This company's reporting system records incidents occurring during work after each shift according to a strict vehicle check policy before handing over the vehicle to the driver on the next shift. Data recorded included all damage and injuries involving the bus and due to bus driver behaviour or other road users. Culpability for traffic accidents (including falls in the bus) was assigned by the driver's manager in collaboration with an insurance team, incorporating such information as the driver's report, photographs, witness reports etc. Three levels of responsibility for the accident were used; none, some and sole. Therefore, in the U.K. sample, drivers' accident record was represented by three culpability variables; number of All accidents, All responsible accidents, and Solely responsible accidents. No self-report data were gathered for this sample.

In the Swedish study, bus accident data were gathered from the archives of GUB (af Wåhlberg, 2002b; 2004). For the present study, number of accidents for the three years before the questionnaire was distributed was used as the dependent variable, regardless of culpability. This was for two reasons. First, DBQ studies have paid little attention to culpability, and instead canvass all accidents (e.g. Blockey \& Hartley, 1995; Rimmö \& Åberg, 1999; Gras et al, 2006). Possible exceptions to this include Dobson, Brown, Ball, Powers and McFadden (1999), and Parker, West, Stradling and Manstead (1995). Second, the project that generated the data was partly designed to investigate whether there was any difference between number of selfreported accidents and archival data (af Wåhlberg, 2002a); adding culpability could have confounded this issue. Separate questions on number of bus and car accidents, 
regardless of culpability, for the last three years were included in the questionnaire. Therefore, the Swedish Bus-DBQ could be tested against three accident variables (self reported bus crashes, company recorded bus crashes and self reported car crashes).

In the Canadian Study, self-report information was gathered on the 1) number of accidents, 2) number of moving violations and 3) accident free kilometers driven in the past two years on the job. In addition, participants also reported the number of 'near misses' they experienced over the past month. Not all of these variables can be said to be valid measures of safety, but they are commonly used within traffic safety research. Drivers indicated whether or not the researchers could see their personnel records for research purposes. The names of these individuals were faxed to the company contact person who provided the information. Of the 190 respondents, $153(80.5 \%)$ allowed access their driving records for the number of accidents and the number of kilometers driven accident free (total-to-date with the company). No more information about their driving records, such as the number of accidents or the number of kilometers driven accident free over just the past two years, nor any information about the accidents (e.g., severity, culpability), could be obtained. Although the information about accident-free kilometers driven is an unusual criterion measure, the company was tracking this information in particular so as to encourage safe driving amongst its employees.

\section{Statistical methods}

Different researchers have used different statistical methods from which to derive DBQ factors; for example principal axis factor or principal components analysis with direct oblimin (Özkan \& Lajunen, 2005; Özkan, Lajunen \& Summala, 2006) or varimax (Özkan, Lajunen, Chliaoutakis, Parker \& Summala, in press) rotation, direct summing of scores (Dobson, Brown, Ball, Powers \& McFadden, 1999; 
Lajunen \& Summala, 2003), or no report of the analysis used (Parker, West, Stradling \& Manstead, 1995; Parker, 1999). However, principal components analysis with varimax (e.g. Reason, Manstead, Stradling, Baxter \& Campbell, 1990; Blockey \& Hartley, 1995; Parker, Reason, Manstead \& Stradling, 1995; Rimmö \& Åberg, 1999; Sullman, Meadows \& Pajo, 2002; Gras et al, 2006) or oblimin (Parker, Lajunen \& Stradling, 1998; Parker, McDonald, Rabbitt \& Sutcliffe, 2000) rotation seems to be the most common choice. Thus, in the present study, principal components analysis was selected for data reduction, with varimax rotation if more than one relevant component was extracted.

Given the somewhat small samples used, component solutions might not always be dependable. Therefore, as a complementary method, it was decided to simply unit-weight the items on the pre-defined factors (e.g., violation) creating a 'forced' scale. It should be remembered that violations of the kind included in the DBQ do not really need to form a reliable scale (i.e., a person is high or low on most items) to be able to predict accident involvement. A person who only engages in speeding violations is still a dangerous driver and could accumulate accidents by this behaviour alone. Therefore, summing the violation items was deemed a valid method under the present circumstances. This approach has also been used by other authors (e.g. Lajunen \& Summala, 2003; Schwebel, Severson, Ball \& Rizzo, in press; King \& Parker, in press).

Measures of association (Pearson correlation and Spearman's rho) were used in this study. Use of the Pearson correlation with accident data as one of the variables has been questioned, due to the restriction of range on this variable. This argument is particularly problematic if accident data are collected over short time periods and with and low-accident risk populations. In most of the present samples 
range restriction was not problematic for the recorded data as is evinced by the high mean values (see Tables 2, 4-6). The main reason for using correlational analyses is that it allows comparison across studies. To supplement the measures of association, however, t-tests were used for analyses of differences between accident-involved and accident-free drivers.

\section{Results}

\section{The U.S. study}

When analysing the U.S. DBQ data, two items concerning gear shifting were deleted due to very low response rates, as most U.S. cars have automatic gearboxes. All item responses were strongly skewed, with very low means. This was probably due to the homogeneous sample of elderly drivers. The remaining U.S. data of forty-eight items was analysed using a principal components analysis (various rotated versions yielded very similar results to the unrotated solution). There were fifteen components with eigenvalues above 1 , but the screeplot indicated that a solution of only one component was most appropriate.

The fourteen items (all were errors) that loaded above .50 on this first factor were included in a second principal components analysis resulting in a single component with an eigenvalue of 4.8 explaining 34.5 percent of the variance. Twelve of the 14 items loaded at .50 or higher. These items then were summed and used as an "error" predictor. In addition, a violation scale was created by summing across the seventeen violation items. These variables were then correlated with crashes, with the results presented in Table 2 . It can be seen that the self-reported variables had stronger effects for the DBQ error variable, while the situation was reversed for the DBQ violation scale. 
The associations between the criterion variables were then investigated. As there were two variants of each of these two data sources, a total of six correlations could be computed. Spearman's rho was selected for these tests, due to the low means for these variables. These associations are shown in Table 3. It can be seen that within each source the correlations were positive and strong. Between sources, however, all associations were negative.

Tables 2-3 about here

\section{The U.K. study}

The fifty items of the U.K. DBQ were analysed using principal components with a varimax rotation ${ }^{3}$. Although there were fifteen factors with an eigenvalue above 1 , the screeplot indicated that a three-factor solution was acceptable in this data set.

The factor-based scores for these three components were created and a violation scale based on the 16 violation items was generated. These were correlated using the Pearson product-moment coefficient with all U.K. accident variables. These results are shown in Table 4. T-tests of the differences in means on the DBQ factors and scale were conducted with accidents/no accidents as the grouping variable, and are also shown in Table 4. As can be seen, no significant results were found. We re-ran the principal components analysis resulting in a three-factor solution, and left the components unrotated. Component-based scales created from this analysis showed weak associated with accidents.

It might be argued that this DBQ version (an early model) was not optimal for accident prediction. However, exactly what version/which items should be

\footnotetext{
${ }^{3}$ In an unrotated solution, forty-three items loaded most strongly on the first factor.
} 
used cannot be ascertained, as there are so many of them (see further information presented in the Discussion). Therefore, to provide the most liberal test of the DBQ in predicting accidents, we conducted yet another components analysis. Starting with the previous components analyses results, all items with a loading below .50 were deleted, leaving twenty-five items. A principal components analysis with varimax raw rotation yielded five components with eigenvalues above 1, but, again, the screeplot indicated a three-component solution to be most appropriate. The first component had nine slips, three mistakes and two violations (31.4 percent explained variance, alpha $.88)$, the second seven violations and one slip (9.6\%), and the third two violations and a slip (7.3\%). Only one item loaded below .50. The correlations between these component-based and the original ones were $>.89$ for each, and the associations for the new ones with accidents very similar to those presented in Table 4, (i.e. weak and not significant). Thus, regardless of how these items were pulled together, they were not able to predict accidents in this sample.

Table 4 about here

\section{The Swedish study}

The thirty-two items of the Bus-DBQ were analysed $(\mathrm{N}=146)$, using principal components with varimax rotation. The screeplot indicated that a two-component solution was most appropriate, where the first explained 33.4 percent of the variance, and the second accounted for 8.1 percent of the variance. The component loadings are shown in Appendix 3. The results suggest that the first component was a general "error" component, while the second consisted mainly of violations. Componentbased scales constructed using these results were uncorrelated. The alphas were 
somewhat higher than most in DBQ research (e.g. Sullman, Meadows \& Pajo, 2002). The two component-based scores and a violation scale created by summing across all violation items were correlated with the three available accident variables and the results are presented in Table 5.

Table 5 about here

\section{The Canadian study}

The fifteen items of the DBQ and the additional cellular telephone use item were analysed, using principal components with varimax rotation. Although six components had eigenvalues greater than 1, the first accounted for most of the variance (19\%) and the screeplot indicated that a one-component solution was most appropriate. Of the 16 items, eight had loadings above 0.40 on this component (see Appendix 4). Thus, a component-based DBQ scale was created using the eight items that loaded on the first component $($ alpha $=.63)$. This scale was a mix of items that were mistakes, slips and violations. In addition, a violation scale was created by summing across all six items of this type. The associations between the accident variables and the DBQ variables are shown in Table 6.

Tables 6 about here

\section{Discussion}

The findings across this four-part study can be summarised as thus: if a significant association between any DBQ factor or scale and accidents was found, it was with a self-reported variable, not objectively recorded data, despite the higher 
means and validities of the latter in all samples. It must be pointed out that there were values for the recorded accident variables that approached significance at times, and in a few instances, the effects were slightly stronger for the recorded variables than for the self-report data. However, this is to be expected, as recorded data had higher means than self-reported data.

These findings lead to the need to take a closer look at the DBQ, this very popular questionnaire with its often-claimed success as a psychometric instrument and accident predictor. Given the statements of various researchers in this area (e.g. "...small differences in factor structures have been reported." (Lajunen, Parker \& Summala, 2004, p. 232)), it could be expected that the DBQ should be homogenous in its content and results. However, the studies using the DBQ actually show a bewildering array of different combinations of items, factors, statistical methods and results.

Starting with items, these differ both in terms of quantity and content. For example, the number included by Özkan, Lajunen, Chliaoutakis, Parker and Summala (in press) was 19, Lajunen and Summala (2003) included 27, Sümer (2003) used 28, Rimmö and Åberg (1999) had 32, Åberg and Rimmö (1998) 104, while Kontogiannis, Kossiavelou and Marmaras (2002) included 112 items. Similarly, the number of factors and their labels differ wildly between studies. The original three factors of violations, errors and lapses (Reason, Manstead, Stradling, Baxter \& Campbell, 1990) have been split further into, for example, highway code violations and aggressive violations (Parker, Lajunen \& Stradling, 1998 mistakes, inattention and inexperience (Åberg \& Rimmö, 1998), while Blockey and Hartley (1995) found two error factors; general and dangerous. Parker, McDonald, Rabbitt and Sutcliffe (2000) reported five factors, and Kontogiannis, Kossiavelou and Marmaras (2002) 
seven. See further the discussion about this in Özkan et al (in press).

It is also interesting to note that researchers have used many different ways of factoring the DBQ, but none of them have clearly stated why a certain type of analysis was used. As the various methods differ somewhat in their results on a given set of data, these unexplained differences are troublesome, as it is possible that results would not have been the same if a single type of analysis had been used. Still, it is often claimed that the DBQ factor structure has been replicated many times (e.g. Rimmö \& Åberg, 1999; Parker, Lajunen \& Stradling, 1998; Gras et al, 2006). Part of this replication phenomenon may be due to the use of methods suited to the occasion. Another result which is often stated by DBQ researchers is that "...mainly violations not errors or lapses Summala, 2004, p. 231; see also Sullman, Meadows \& Pajo, 2002 for the same type of statement). However, counting the number of studies with different results indicate that errors and lapses, taken together, have been significant predictors of accidents about as many times as the various violation factors (Parker, Reason, Manstead \& Stradling, 1995; Parker, West, Stradling \& Manstead, 1995; Lawton, Parker, Stradling \& Manstead, 1997; Meadows, Stradling \& Lawson, 1998; Dobson, Brown, Ball, Powers \& McFadden, 1999 Rimmö \& Åberg, 1999; Parker, McDonald, Rabbitt \& Sutcliffe, 2000; Kontogiannis, Kossiavelou \& Marmaras, 2002; Mesken, Lajunen \& Summala, 2002; Sümer, 2003; Özkan \& Lajunen, 2005; Gras et al, 2006; Özkan et al, in press; Bener, Özkan \& Lajunen, in press). Only Blockey and Hartley (1995) did not find an effect for any of the factors. On the other hand, about one third of all DBQ studies have not reported on accident associations.

It is apparent that the DBQ literature is characterized by much less coherence than is usually implied by the researchers active in this field, including the 
power to predict accidents. Specific concerns with the DBQ include questions such as, "What is the impact of items about hitting things while driving?" (e.g. Chapman, Roberts \& Underwood, 2000, see also items 12 and 31 in Appendix 2, and item 12 in Appendix 4). Including an item in the independent variable that seems to measure partly the same thing as the dependent variable would load the investigation in favour of finding an association.

One limitation of the present study was the small $\mathrm{n}$ in the samples used. However, it should also be remembered that the mean number of accidents and the variation in professional driver populations used were much higher than those usually used for DBQ studies, and any effect should therefore be easier to find.

It could also be claimed that the UK study was flawed, because it used a DBQ version for car drivers on a population which it was not intended for, and the dependent variable was bus accidents. However, Sullman, Meadows and Pajo (2002) did find a significant association between truck drivers' self-reported accidents and the violation factor of a DBQ-version which was not specifically adapted to truck driving. Also, this possible problem could not explain the findings in the Swedish sample of the present study, where self-reported bus driving behaviours were predictive of both self-reported bus and car accidents.

Based on the results of the analyses reported here, it may be concluded that the items of the DBQ can weakly predict self-reported accidents, but not company - or state-recorded (i.e. objective) data. These results are in line with the suggested hypothesis of a common method variance effect, specifically the consistency motif. This explanation also applies to other driver behaviour questionnaires, where self-reported attitudes, behaviour, personality, etc. are correlated with self-reported accidents, and could explain why the DBQ has yielded 
different accident predictors in different studies. Further, the present findings suggest that using self-reported data describing behaviours, attitudes, personality, etc. is rather overstated as a means of understanding the link between behaviour and actual accident involvement.

In general, the main arguments of those who use self-reported crash data are that state sources are even worse concerning their validity as a reflection of the total number, and that significant findings using self-reported accidents are proof that the real associations must be even stronger, as the dependent variable contains some error. The problem is that none of the DBQ studies referenced herein has tested this assumption, and that the present study would seem to indicate that it may be erroneous. It can also be questioned whether sheer number of accidents is a good indicator of validity, in terms of what is actually important to predict. Given that state records tend to contain the most serious accidents, and those are the ones that are most important to prevent, a method that is not able to predict this kind of traffic accident involvement is of little use.

The main method employed for testing whether self-reports of crashes lead to inflated results is to do what has been done here: testing to see if other sources of the dependent variable yield different results. Unfortunately, few researchers seem to have used such precaution, with Arthur et al (2001) and Arthur, Bell, Edwards, Day, Tubre and Tubre (2005) being two of the exceptions. Also, it could be useful to try to ascertain whether self-reported accidents are actually the same as the ones found within company/state databases. This too, is very uncommon in the literature, and so far the evidence points to substantial discrepancies between these sources (McGuire, 1973; Smith, 1976; af Wåhlberg, 2002a). This leads to an important question: If the accidents that people report are often not the ones that are found in the 
company records, then what accidents are they reporting about? No research concerning this question has been located.

Finally, it is clear from the present study that the DBQ (and other driver behaviour questionnaires) should be used with caution by both researchers and practitioners. Despite its popularity, the evidence for its accident predictive power appears to be slight. It is a common rule of social interaction and logic that those who make a claim are those who carry the weight of providing proof in favour of it. Within science, it is equally common, it would seem, that it is those who dispute a claim who need to do the research to show the error. The challenge now is for those who rely on self-reported accident data to provide evidence that validates this measure against objective records. By extension, the validity of self-reports of other data crucial to traffic safety research, such as self-reported exposure measures, may also deserve scrutiny.

\section{Acknowledgements}

The data used in this paper had been generously made available by a major UK bus company and Gamla Uppsalabuss in Sweden, and by Cynthia Owsley and Gerald McGwin (University of Alabama) in the US.

Author notes:

Anders af Wåhlberg graduated with a B. A. in history (1994) and an M. A. in psychology (1996), and thereafter worked as a research assistant at Center for Risk Research, Stockholm School of Economics 1996-1998. He received his PhD in psychology 2006, at the Department of Psychology, Uppsala University, Sweden. Main research interests are driver behavior, traffic accidents and research methodology, most often together.

Lisa Dorn graduated with a BSc in Human Psychology in 1987 and was awarded a $\mathrm{PhD}$ on 'Individual and Group Difference in Driving Behaviour' in 1992, both from Aston University, UK. After several post-doctoral positions, Lisa was appointed as Director of the Driving Research Group at Cranfield University in 2001. Her research 
interests are driver training and education especially in the use of self-assessment methods.

Theresa J.B. Kline is a professor in the Department of Psychology at the University of Calgary. She has an active research program in the area of team performance, psychometrics, organizational effectiveness, and work attitudes. Theresa has published two books on teams, Teams that Lead (2003) and Remaking Teams (1999), and one on psychometrics, Psychological Testing (2005), and over 50 peer-reviewed articles. Theresa teaches statistics/methods and organizational psychology at both the undergraduate and graduate levels. She has an active organizational consulting practice with projects ranging from individual and organizational assessment to teams and leadership to strategic alignment.

\section{References}

ARTHUR, W.Jr. 1991, Individual differences in the Prediction and Training of Complex Perceptual-Motor Skill Tasks: The Development and Validation of The Computer-Administered Test of Visual Selective Attention. Technical report. Texas A\&M University.

ARTHUR, W.Jr., BARRETT, G.V., and ALEXANDER, R.A. 1991, Prediction of vehicular accident involvement: A meta-analysis. Human Performance, 4, pp. 89-105.

ARTHUR, W.Jr., TUBRE, T.C., DAY, E., SHEEHAN, M.K., SANCHEZ-KU, M.L., PAUL, D.S., PAULUS, L.E., and ARCHULETA, K.D. 2001, Motor vehicle crash involvement and moving violations: Convergence of self-report and archival data. Human Factors, 43, pp. 1-11.

ARTHUR, W.Jr., BELL, S.T., EDWARDS, B.D., DAY, E.A., TUBRE, T.C., and TUBRE, A.H. 2005, Convergence of self-report and archival motor vehicle crash 
involvement data: A two-year longitudinal follow up. Human Factors, 47, pp. 303313.

BARKLEY, R.A., MURPHY, K.R., DU PAUL, G. J., and Bush, T. 2002, Driving in young adults with attention deficit hyperactivity disorder: Knowledge, performance, adverse outcomes, and the role of executive functioning. Journal of the International Neuropsychological Society, 8, pp. 655-672.

BLOCKEY, P.N., and HARTLEY, L.R. 1995, Aberrant driving behaviour: errors and violations. Ergonomics, 38, pp. 1759-1771.

BROWN, P.L., and BERDIE, R.F. 1960, Driver behavior and scores on the MMPI. Journal of Applied Psychology, 44, pp. 18-21.

CHAPMAN, P., ROBERTS, K., and UNDERWOOD, G. 2000, A study of the accidents and behaviours of company car drivers. In G. B. Grayson (Ed.), Behavioural Research in Road Safety X. Crowthorne: Transport Research Laboratory.

CHAPMAN, P., and UNDERWOOD, G. 2000, Forgetting near-accidents: The roles of severity, culpability and experience in the poor recall of dangerous driving situations. Applied Cognitive Psychology, 14, pp. 31-44.

CAIRD, J.K., and KLINE, T.J. 2004, The relationships between organizational and individual variables to on-the-job driver accidents and accident-free kilometres. Ergonomics, 47, pp. 1598-1613. 
CHOU, M., MIYAZAKI, A., and MARUYAMA, K. 1994, Causal analysis of aptitude, driving behavior, and accidents through the use of covariance structure analysis: Based on self-reported data. Tohoku Psychologica Folia, 53, pp. 21-26.

DOBSON, A., BROWN, W., BALL, J., POWERS, J., and MCFADDEN, M. 1999, Women drivers' behaviour, socio-demographic characteristics and accidents. Accident Analysis and Prevention, 31, pp. 525-535.

ELANDER, J., WEST, R.J., and FRENCH, D.J. 1993, Behavioral correlates of individual differences in road-traffic crash risk: An examination of methods and findings. Psychological Bulletin, 113, pp. 279-294.

Fergusson, D. M., Horwood, L. J., \& Boden, J. M. (in press). Is driving under the influence of cannabis becoming a greater risk to driver safety than drink driving? Findings from a longitudinal study. Accident Analysis and Prevention, , -.

GOLDING, A.P. 1983, Differential accident involvement: A literature survey. Council for Scientific and Industrial Research Reports, PERS 356: 44.

GRAS, M.E., SULLMAN, M.J., CUNILL, M., PLANES, M., AYMERICH, M., and FONT-MAYOLAS, S. 2006, Spanish drivers and their aberrant driving behaviours. Transportation Research Part F, 9, pp. 129-137. 
HANSEN, C.P. 1988, Personality characteristics of the accident involved employee. Journal of Business and Psychology, 2, pp. 346-365.

HARTLEY, L.R., and EL HASSANI, J. 1994, Stress, violations and accidents. Applied Ergonomics, 25, pp. 221-230.

KING, Y., and PARKER, D. in press, Driving violations, aggression and perceived consensus. Revue Européenne de Psychologie Appliquée,

KNOUSE, L.E., BAGWELL, C.L., BARKLEY, R.A., and MURPHY, K.R. 2005, Accuracy of self-evaluation in adults with ADHD: evidence from a driving study. Journal of Attention Disorders, 8, pp. 221-234.

KONTOGIANNIS, T., KOSSIAVELOU, Z., and MARMARAS, N. 2002, Self reports of aberrant behaviour on the roads: Errors and violations in a sample of Greek drivers. Accident Analysis and Prevention, 34, pp. 381-399.

LAJUNEN, T., and SUMMALA, H. 2003, Can we trust self-reports of driving? Effects of impression management on driver behaviour questionnaire responses. Transportation Research Part F, 6, pp. 97-107.

LARSON, G.E., and MERRITT, C.R. 1991, Can accidents be predicted? An empirical test of the Cognitive Failures Questionnaire. Applied Psychology: An International Review, 40, pp. 37-45. 
LESTER, J. 1991, Individual differences in accident liability: review of the literature. Research Report 306. Crowthorne: Transport and Road Research Laboratory.

MAYCOCK, G. and LESTER, J. 1995, Accident liability of car drivers: follow-up study. In G. B. Grayson (Ed., Behavioural Research in Road Safety V, pp. 106-120. Transport Research Laboratory, Crowthorne.

MAYCOCK, J., LOCKWOOD, C., and LESTER, J.F. 1991, The accident liability of car drivers. TRRL Research Report No. 315. Crowthorne: Transport and Road Research Laboratory.

MCGUIRE, F.L. 1972, Smoking, driver education, and other correlates of accidents among young males. Journal of Safety Research, 4, pp. 5-11.

MCGUIRE, F.L. 1973, The nature of bias in official accident and violation records. Journal of Applied Psychology, 57, pp. 300-305.

MCGUIRE, F.L. 1976, Personality factors in highway accidents. Human Factors, 18, pp. 433-442.

MCGWIN, G., OWSLEY, C., and BALL, K. 1998, Identifying crash involvement among older drivers: Agreement between self-report and state records. Accident Analysis and Prevention, 30, pp. 781-791. 
MOORMAN, R.H., and PODSAKOFF, P.M. 1992, A meta-analytic review and empirical test of the potential confounding effects of social desirability response sets in organizational behaviour research. Journal of Occupational and Organizational Psychology, 65, pp. 131-149.

OSGOOD, C. E., and TANNENBAUM, P. H. 1955, The principle of congruity in the prediction of attitude change. Psychological Review, 62, pp. 42-55.

OWSLEY, C., BALL, K., SLOANE, M.E., ROENKER, D.L., and BRUNI, J.R. 1991, Visual/cognitive correlates of vehicle accidents in older drivers. Psychology and Aging, 6, pp. 403-415.

OWSLEY, C., MCGWIN, G.Jr., and MCNEAL, S.F. 2003, Impact of impulsiveness, venturesomeness, and empathy on driving in older adults. Journal of Safety Research, 34, pp. 353-359.

OWSLEY, C., MCGWIN, G.J., SLOANE, M.E., WELLS, J., STALVEY, B.T., and GAUTHREAUX, S. 2002, Impact of cataract surgery on motor vehicle crash involvement by older adults. JAMA, 288, pp. 841-849.

OWSLEY, C., STALVEY, B., WELLS, J., and SLOANE, M.E. 1999, Older drivers and cataract: Driving habits and crash risk. Journals of Gerontology Series A, Biological Sciences and Medical Sciences, 54A. pp. M203-M211. 
OWSLEY, C., STALVEY, B.T., WELLS, J., SLOANE, M.E., and MCGWIN, J.G. 2001, Visual risk factors for crash involvement in older drivers with cataract. Archives of Ophthalmology, 119, pp. 881-887.

PARKER, D. 1999, Elderly drivers and their accidents: The Ageing Driver Questionnaire. In G. Grayson Behavioural Research in Road Safety I, pp. 169-178. Crowthorne: Transport Research Laboratory.

PARKER, D., MCDONALD, L., RABBITT, P., and SUTCLIFFE, P. 2000, Elderly drivers and their accidents: the Aging Driver Questionnaire. Accident Analysis and Prevention, 32, pp. 751-759.

PARKER, D., LAJUNEN, T., and STRADLING, S.G. 1998, Attitudinal predictors of interpersonally aggressive violations on the road. Transportation Research Part $F, 1$, pp. 11-24.

PARKER, D., REASON, J.T., MANSTEAD, A.S., and STRADLING, S. G. 1995, Driving errors, driving violations and accident involvement. Ergonomics, 38, pp. 1036-1048.

PECK, R.C. 1993, The identification of multiple accident correlates in high risk drivers with specific emphasis on the role of age, experience and prior traffic violation frequency. Alcohol, Drugs and Driving, 9, pp. 145-166. 
PODSAKOFF, P. M., MACKENZIE, S. B., LEE, J. Y., \& PODSAKOFF, N. P. 2003, Common method biases in behavioral research: A critical review of the literature and recommended remedies. Journal of Applied Psychology, 88, pp. 879903.

REASON, J. 1987, Generic Error-Modelling System (GEMS): a cognitive framework for locating common human error forms. In J. Rasmussen, K. Duncan, and J. Leplat, New technology and human error. Chichester: Wiley.

REASON, J., MANSTEAD, A., STRADLING, S., BAXTER, J., and CAMPBELL, K. 1990, Errors and violations on the roads: a real distinction? Ergonomics, 33, pp. 1315-1332.

RIMMÖ, P.-A. and ÅBERG, L. 1999, On the distinction between violations and errors: Sensation seeking associations. Transportation Research Part F, 2, pp. 151166.

SCHUSTER, D.H., and GUILFORD, J.P. 1962, The psychometric prediction of problem drivers. Traffic Safety Research Review, 6, 16-20.

SCHWEBEL, D.C., SEVERSON, J., BALL, K.K., and RIZZO, M. in press,. Individual differences factors in risky driving: The roles of anger/hostility, conscientiousness, and sensation seeking. Accident Analysis and Prevention 
SIGNORI, E.I., and BOWMAN, R.G. 1974, On the study of personality factors in research on driving behavior. Perceptual and Motor Skills, 38, 1067-1076.

SMITH, D.I. 1976, Official driver records and self-reports as sources of accident and conviction data for research purposes. Accident Analysis and Prevention, 14, 439-442.

SMITH, D.I., and KIRKHAM, R.W. 1982, Relationship between intelligence and driving record. Accident Analysis and Prevention, 14, 439-442.

SOBEL, R., and UNDERHILL, R. 1976, Family disorganization and teenage auto accidents. Journal of Safety Research, 8, pp. 8-18.

SPECTOR, P.E. 2006, Method variance in organizational research: Truth or urban legend? Organizational Research Methods, 9, pp. 221-232.

SULLMAN, M..J., MEADOWS, M.L., and PAJO, K.B. 2002, Aberrant driving behaviours amongst New Zealand truck drivers. Transportation Research Part F, 5, pp. 217-232.

SÜMER, N. 2003, Personality and behavioral predictors of traffic accidents: testing a contextual mediated model. Accident Analysis and Prevention, 35, pp. 949-964.

SZLYK, J.P., SEIPLE, W., and VIANA, M. 1995, Relative effects of age and compromised vision on driving performance. Human Factors, 37, pp. 430-436. 
WESTERMAN, S.J., and HAIGNEY, D. 2000, Individual differences in driver stress, error and violation. Personality and Individual Differences, 29, pp. 981-998.

AF WÅHLBERG, A.E. 2002a, On the validity of self-reported traffic accident data. E140 Proceedings of Soric'02. Available at www.psyk.uu.se/hemsidor/busdriver

AF WÅHLBERG, A.E. 2002b, Characteristics of low speed accidents with buses in public transport. Accident Analysis and Prevention, 34, pp. 637-647.

AF WÅHLBERG, A.E. 2003, Some methodological deficiencies in studies on traffic accident predictors. Accident Analysis and Prevention, 35, pp. 473-486.

AF WÅHLBERG, A.E. 2004, Characteristics of low speed accidents with buses in public transport. Part II. Accident Analysis and Prevention, 36, pp. 63-71.

AF WÅHLBERG, A.E., and DORN, L. 2007, Culpable versus non-culpable traffic accidents; what is wrong with this picture? Journal of Safety Research, 38, pp. 453459.

ÅBERG, L., and RIMMÖ, P.-A. 1998, Dimensions of aberrant driver behaviour. Ergonomics, 41, pp. 39-56.

ÖZKAN, T., and LAJUNEN, T. 2005, A new addition to DBQ: Positive Driver Behaviours Scale. Transportation Research Part F, 8, pp. 355-368. 
ÖZKAN, T., LAJUNEN, T., and SUMMALA, H. 2006, Driver Behaviour

Questionnaire: A follow-up study. Accident Analysis and Prevention, 38, pp. 386-395.

ÖZKAN, T., LAJUNEN, T., CHLIAOUTAKIS, J.E., PARKER, D., and

SUMMALA, H. in press, Cross-cultural differences in driving behaviours: A

comparison of six countries. Transportation Research Part F, 
Appendix 1: The items included in the U.S. Study Error factor.

Component loadings from a principal components analysis with varimax rotation.

Item (numbers from original)

14. Miss your exit on an interstate and have to make a lengthy detour

20. Try to change lanes without first checking your mirror, and then be honked at by the car behind you which is already in the lane

24. In a line of vehicles turning left on to a main road, pay such close attention to the oncoming traffic that you nearly hit the car in front of you

27. Lost in thought or distracted, you fail to notice someone on the side waiting to cross in a pedestrian crossing and you drive through the crosswalk

29. Misjudge the speed of the oncoming vehicle when passing a car

31. Fail to notice someone stepping out from behind a bus or parked car until it is nearly too late

33. Pass a single line of stationary or slow-moving vehicles, only to discover that they were in a line to get through one-lane construction zone

35. Cut the corner on a left-hand turn and have to swerve to avoid an oncoming vehicle

37. Fail to read the signs correctly at an intersection and turn onto the wrong road

39. Ignore the yield signs and narrowly avoid colliding with traffic that has the right of way

41. Attempt to pass a vehicle that you hadn't noticed was signaling its' intention to turn left

45. Fail to notice pedestrians crossing when turning into a side-street from a main road

48. Brake too quickly on a slippery road and skid

49. Misjudge your turning space when turning left and narrowly miss collision

Loading $-0.52$

$-0.47$

$-0.54$

$-0.53$

$-0.65$

$-0.56$

$-0.49$

$-0.62$

$-0.57$

$-0.64$

$-0.62$

$-0.67$

$-0.56$ 
Appendix 2: The items of the UK sample

Component loadings from a principal components analysis with varimax rotation. $\mathrm{N}=238$.

\begin{tabular}{|c|c|c|c|}
\hline Item & $\begin{array}{l}\text { Component } \\
1 \text { loadings }\end{array}$ & $\begin{array}{l}\text { Component } \\
2 \text { loadings }\end{array}$ & $\begin{array}{l}\text { Component } \\
3 \text { loadings }\end{array}$ \\
\hline 1. Attempt to drive away from traffic lights in third gear & 0.48 & & \\
\hline $\begin{array}{l}\text { 2. Check your speedometer and discover that you are } \\
\text { unknowingly travelling faster that the legal limit }\end{array}$ & & & 0.33 \\
\hline 3. Lock yourself out of your car with the keys still inside & & & 0.37 \\
\hline $\begin{array}{l}\text { 4. Become impatient with a slow driver in the outer lane and } \\
\text { overtake on the inside }\end{array}$ & & & 0.72 \\
\hline $\begin{array}{l}\text { 5. Drive as fast along country roads at night on dipped lights } \\
\text { as on full beam }\end{array}$ & & & 0.48 \\
\hline $\begin{array}{l}\text { 6. Attempt to drive away without first having switched on the } \\
\text { ignition }\end{array}$ & & & 0.50 \\
\hline $\begin{array}{l}\text { 7. Drive especially close or 'flash' the car in front as a signal } \\
\text { for that driver to go faster or get out of your way }\end{array}$ & & & 0.68 \\
\hline 8. Forget where you left your car in a multi-level car park & & & 0.34 \\
\hline $\begin{array}{l}\text { 9. Distracted or preoccupied, realise belatedly that the vehicle } \\
\text { ahead has slowed, and have to slam on the brakes to avoid a } \\
\text { collision }\end{array}$ & 0.53 & & \\
\hline $\begin{array}{l}\text { 10. Intend to switch on the windscreen wipers, but switch on } \\
\text { the lights instead, or vice versa }\end{array}$ & 0.49 & & \\
\hline $\begin{array}{l}\text { 11. Turn left on to a main road into the path of an oncoming } \\
\text { vehicle that you hadn't seen, or whose speed you had } \\
\text { misjudged }\end{array}$ & 0.45 & & \\
\hline $\begin{array}{l}\text { 12. Misjudge your gap in a car park and nearly (or actually) } \\
\text { hit adjoining vehicle }\end{array}$ & 0.46 & & \\
\hline $\begin{array}{l}\text { 13.'Wake up' to realise that you have no clear recollection of } \\
\text { the road along which you have just travelled }\end{array}$ & 0.54 & & \\
\hline $\begin{array}{l}\text { 14. Miss your exit on a motorway and have to make a lengthy } \\
\text { detour }\end{array}$ & 0.44 & & \\
\hline $\begin{array}{l}\text { 15. Forget which gear you are currently in and have to check } \\
\text { with your hand }\end{array}$ & 0.59 & & \\
\hline $\begin{array}{l}\text { 16. Stuck behind a slow-moving vehicle on a two-lane } \\
\text { highway, you are driven by frustration to try to overtake in } \\
\text { risky circumstances }\end{array}$ & & & 0.51 \\
\hline $\begin{array}{l}\text { 17. Intending to drive to destination A, you 'wake up' to find } \\
\text { yourself en route to B, where the latter is the more usual } \\
\text { journey }\end{array}$ & 0.50 & & \\
\hline 18. Take a chance and cross on lights that have turned red & & 0.54 & \\
\hline $\begin{array}{l}\text { 19. Angered by another driver's behaviour, you give chase } \\
\text { with the intention of giving him/her a piece of your mind }\end{array}$ & & 0.40 & \\
\hline $\begin{array}{l}\text { 20. Try to overtake without first checking your mirror, and } \\
\text { then get hooted at by the car behind which has already begun } \\
\text { it's overtaking manoeuvre }\end{array}$ & & 0.57 & \\
\hline $\begin{array}{l}21 . \text { Deliberately disregard the speed limits late at night or } \\
\text { very early in the morning }\end{array}$ & & & 0.49 \\
\hline $\begin{array}{l}\text { 22. Forget when your road tax/insurance expires and discover } \\
\text { that you are driving illegally }\end{array}$ & 0.40 & & \\
\hline $\begin{array}{l}23 . \text { Lost in thought, you forget that your lights are on full } \\
\text { beam until 'flashed' by other motorists }\end{array}$ & 0.56 & & \\
\hline $\begin{array}{l}\text { 24. On turning left, nearly hit a cyclist who has come up on } \\
\text { your inside }\end{array}$ & 0.56 & & \\
\hline $\begin{array}{l}\text { 25. In a queue of vehicles turning left on to a main road, pay } \\
\text { such close attention to the traffic approaching from the right } \\
\text { that you nearly hit the car in front }\end{array}$ & 0.60 & & \\
\hline $\begin{array}{l}\text { 26. Drive back from a party, restaurant, or pub, even though } \\
\text { you realise that you may be over the legal blood-alcohol limit }\end{array}$ & & 0.36 & \\
\hline 27. Have an aversion to a particular class of road user, and & & & 0.41 \\
\hline
\end{tabular}




\begin{tabular}{|c|c|c|c|}
\hline indicate your hostility by whatever means you can & & & \\
\hline $\begin{array}{l}\text { 28. Lost in thought or distracted, you fail to notice someone } \\
\text { waiting at a zebra crossing, or a pelican crossing light that has } \\
\text { just turned red }\end{array}$ & & 0.51 & \\
\hline 29. Park on a double-yellow line and risk a fine & & 0.42 & \\
\hline 30. Misjudge speed of oncoming vehicle when overtaking & & 0.59 & \\
\hline $\begin{array}{l}\text { 31. Hit something when reversing that you had not previously } \\
\text { seen }\end{array}$ & 0.37 & & \\
\hline $\begin{array}{l}\text { 32. Fail to notice someone stepping out from behind a bus or } \\
\text { parked vehicle until it is nearly too late }\end{array}$ & & 0.31 & \\
\hline $\begin{array}{l}\text { 33. Plan your route badly, so that you meet traffic congestion } \\
\text { you could have avoided }\end{array}$ & 0.33 & & \\
\hline $\begin{array}{l}\text { 34. Overtake a single line of stationary or slow-moving } \\
\text { vehicles, only to discover that they were queuing to get } \\
\text { through a one-lane gap or roadwork lights }\end{array}$ & & & 0.35 \\
\hline $\begin{array}{l}\text { 35. Overtake a slow-moving vehicle on the inside lane or hard } \\
\text { shoulder of a motorway }\end{array}$ & & 0.28 & \\
\hline $\begin{array}{l}\text { 36. Cut the corner on a right-hand turn and have to swerve } \\
\text { violently to avoid an oncoming vehicle }\end{array}$ & & 0.62 & \\
\hline $\begin{array}{l}\text { 37. Get into the wrong lane at a roundabout or approaching a } \\
\text { road junction }\end{array}$ & 0.61 & & \\
\hline $\begin{array}{l}\text { 38. Fail to read the signs correctly, and exit from a } \\
\text { roundabout on the wrong road }\end{array}$ & 0.56 & & \\
\hline $\begin{array}{l}\text { 39. Fail to give way when a bus is signalling its intention to } \\
\text { pull out }\end{array}$ & 0.36 & & \\
\hline $\begin{array}{l}\text { 40. Ignore 'give way' signs, and narrowly avoid colliding } \\
\text { with traffic having right of way }\end{array}$ & & 0.63 & \\
\hline $\begin{array}{l}\text { 41. Fail to check your mirror before pulling out, } \\
\text { changing lanes, turning, etc }\end{array}$ & & 0.67 & \\
\hline $\begin{array}{l}\text { 42. Attempt to overtake a vehicle that you hadn't noticed was } \\
\text { signalling its intention to turn right }\end{array}$ & & 0.51 & \\
\hline $\begin{array}{l}\text { 43. Deliberately drive the wrong way down a deserted one- } \\
\text { way street }\end{array}$ & & 0.57 & \\
\hline $\begin{array}{l}\text { 44. Disregard red lights when driving late at night along } \\
\text { empty roads }\end{array}$ & & 0.56 & \\
\hline $\begin{array}{l}\text { 45. Drive with only 'half-an-eye' on the road while looking at } \\
\text { a map, changing a cassette or radio channel, etc }\end{array}$ & & 0.47 & \\
\hline $\begin{array}{l}\text { 46. Fail to notice pedestrians crossing when turning into a } \\
\text { side-street from a main road }\end{array}$ & 0.46 & & \\
\hline 47. Get involved in unofficial 'races' with other drivers & & & 0.57 \\
\hline $\begin{array}{l}\text { 48. 'Race' oncoming vehicles for a one-car gap on a narrow } \\
\text { or obstructed road }\end{array}$ & & 0.54 & \\
\hline $\begin{array}{l}\text { 49. Brake too quickly on a slippery road and/or steer the } \\
\text { wrong way in a skid }\end{array}$ & & 0.56 & \\
\hline $\begin{array}{l}\text { 50. Misjudge your crossing interval when turning right and } \\
\text { narrowly miss collision }\end{array}$ & & 0.64 & \\
\hline
\end{tabular}




\section{Appendix 3: The Swedish sample Bus Driver Behaviour Questionnaire}

New, bus-specific, items are marked with *.

Component loadings from principal components analysis with varimax rotation.

Instruction:

Estimate how often you do the following when driving a bus, on a six-point scale from 'Never' to 'Very often'.

C: When I drive a bus, it happens that I...

1. Deliberately exceed speed limit on main roads during low traffic

2. Queuing, you pay such close attention to the mainstream of traffic that you nearly hit the car in front.

3 . Exceed the speed limit to catch up or avoid being late *

4. Fail to notice "green arrow" at traffic signal allowing you to turn

5. Fail to check your rear-view mirror before pulling out from a bus stop

*

6. Fail to see passengers at a stop and have to brake strongly *

7. Deliberately turn onto a main road just in front of oncoming vehicle although no other traffic is approaching

8. Turning just in front of pedestrian although he's got "walk now" signal

\begin{tabular}{|l|l|l|}
\hline Type of behavior & $\begin{array}{c}\text { Component } \\
1 \\
\text { loadings }\end{array}$ & $\begin{array}{c}\text { Component } \\
2 \\
\text { loadings }\end{array}$ \\
\hline Violation & & 0.76 \\
\hline Slip & & 0.56 \\
\hline Violation & & 0.76 \\
\hline Slip & 0.68 & \\
\hline Mistake & 0.58 & \\
\hline Slip? & 0.59 & \\
\hline Violation & & 0.64 \\
\hline Violation? & 0.54 & \\
\hline
\end{tabular}

\begin{tabular}{|c|c|c|c|}
\hline D: When I drive a bus, it happens that I... & Type of behavior & $\begin{array}{c}\text { Component } 1 \\
\text { loadings }\end{array}$ & $\begin{array}{c}\text { Component } 2 \\
\text { loadings }\end{array}$ \\
\hline 1. Deliberately disregard speed limit to follow traffic flow & Violation & & 0.72 \\
\hline 2. Take more passengers than allowed $*$ & Violation & & 0.49 \\
\hline 3. Forget to loosen the parking brake when driving off & Lapse & 0.64 & \\
\hline 4. Forget to stop at a bus stop when a passenger want to leave $*$ & Lapse & 0.56 & \\
\hline 5. Talk to passengers or colleagues while driving * & Violation & & 0.47 \\
\hline 6. Sell tickets while the bus is moving $*$ & Violation & & 0.42 \\
\hline 7. Fail to notice when a traffic-signal turns green & Slip & 0.61 & \\
\hline 8. Drive over the curb with your rear wheels $*$ & Slip & 0.63 & \\
\hline 9. Drive to the wrong terminus in the morning $*$ & Lapse & 0.44 & \\
\hline 10. Take a wrong turn en route $*$ & Lapse & 0.67 & \\
\hline 11. Try to drive away despite the back doors being open $*$ & Lapse & 0.68 & \\
\hline 12. Read the time table wrong and start at the wrong time * & Mistake & 0.65 & \\
\hline 13. Feel unsure about the route you are driving * & Lapse & 0.58 & \\
\hline 14. Force a cyclist, who has come up along the bus, sideways * & Violation? & & 0.67 \\
\hline $\begin{array}{l}\text { 15. Drive especially close to the car in front as a signal to its } \\
\text { driver to go faster or get out of the way }\end{array}$ & Violation & & 0.63 \\
\hline $\begin{array}{l}\text { 16. Forget to dip the lights when driving during dark hours and is } \\
\text { reminded by other drivers flashing their lights }\end{array}$ & Lapse & 0.49 & \\
\hline 17. Speed up at traffic lights at a green /yellow phase & Violation & & 0.68 \\
\hline $\begin{array}{l}\text { 18. Turn left onto a main road into the path of an oncoming } \\
\text { vehicle that you hadn't seen, or whose speed you misjudged }\end{array}$ & Mistake & 0.54 & \\
\hline $\begin{array}{l}\text { 19. Intend to reverse and find that the bus is moving forward } \\
\text { because it's in the wrong gear. }\end{array}$ & Slip & 0.39 & \\
\hline $\begin{array}{l}\text { 20. Misjudge the road surface and when braking find the distance } \\
\text { to stop to be longer than you expected }\end{array}$ & Slip & & 0.45 \\
\hline $\begin{array}{l}\text { 21. Switch on e.g. wipers, when you meant to switch on } \\
\text { something else, such as headlights }\end{array}$ & Slip & 0.50 & \\
\hline $\begin{array}{l}22 . \text { Fail to the read the day communication and drive the wrong } \\
\text { way at a road work area * }\end{array}$ & Slip & 0.58 & \\
\hline $\begin{array}{l}\text { 23. Turn left onto a main road into the path of an oncoming } \\
\text { vehicle that you hadn't seen, or whose speed you misjudged }\end{array}$ & Slip & & 0.50 \\
\hline 24. Cut the bends and occasionally drive in your right lane when & Violation & & 0.34 \\
\hline
\end{tabular}


Comments on some of the bus-specific items:

C5: This item was only slightly changed, from pulling out and changing lanes in general, to the more specific situation of the bus stop.

D8: When driving a long vehicle, like a bus, it is very important not to start turning before the rear wheels have passed all obstacles on the side that you are turning to, like the corner of the curb, or you will hit it.

D5: This is not allowed, but very common.

D11: In Sweden, the brakes on buses are automatically on when any door is open. The back doors are normally on automatic and will close when someone has passed through. However, if, for example, someone is unloading something, like a baby carrier, the driver will open the doors manually. After doing this, the driver will often have to attend to other passengers entering through the front door, and forget that the back door is on manual and therefore still open when he has closed the front door and tries to move off.

D14: A slight alteration of the original "On turning right, nearly hit a cyclist who come up on your inside". Also, this item is particularly pertinent in Uppsala, a university town with many cyclists. D22: The daily communication consists of messages that the drivers are supposed to read before they start their day. These messages often concern temporary changes in the routes. 
Appendix 4: The Canadian sample DBQ (items and factor loadings)

Component loadings from principal components analysis with varimax rotation.

\begin{tabular}{|c|c|}
\hline Item & Loading \\
\hline 1. Become impatient with a slow driver and pass on the right & .239 \\
\hline $\begin{array}{l}\text { 2. Drive too closely to the car in front as a signal to its driver to go faster or get out of } \\
\text { the way }\end{array}$ & .368 \\
\hline $\begin{array}{l}\text { 3. Attempt to pass someone on an undivided road that you hadn't noticed to be signaling } \\
\text { a left turn }(E)\end{array}$ & .435 \\
\hline 4. Run yellow lights $(V)$ & .510 \\
\hline 5. Fail to notice pedestrians are crossing & .380 \\
\hline 6. Angered by another driver's behaviour, you yell or gesture at them $(V)$ & .406 \\
\hline 7. Choose to exceed the speed limits when the police are not around $(V)$ & .420 \\
\hline 8. On turning right, nearly hit a cyclist who has come up on your inside & .381 \\
\hline $\begin{array}{l}\text { 9. When merging, you pay such close attention to the main stream of traffic that you } \\
\text { nearly hit the car in front of you }(E)\end{array}$ & .501 \\
\hline 10. Drive even though you consumed alcohol & .373 \\
\hline $\begin{array}{l}\text { 11. Underestimate the speed of an oncoming vehicle when passing on an undivided road } \\
\text { (E) }\end{array}$ & .613 \\
\hline 12. Hit something while backing up that you had not previously seen & .374 \\
\hline 13. Miss "Yield" or "Stop" signs; narrowly avoiding a collision $(E)$ & .598 \\
\hline 14. Fail to check your rearview mirror before pulling out, changing lanes, etc. & .230 \\
\hline 15. Brake too quickly on a slippery road, or steer the wrong way into a skid (E) & .647 \\
\hline 16. I use the cellular phone while driving & .304 \\
\hline
\end{tabular}

Note: Italicised items were used to create the DBQ scale, $\mathrm{V}=$ violation, $\mathrm{E}=$ error 
Table 1: Descriptive data for the four samples; number of drivers, percentage male drivers, percentage ethnic mix, mean /std for age and experience.

\begin{tabular}{|l|l|l|l|l|l|}
\hline Sample & $\begin{array}{l}\text { Number of } \\
\text { drivers }\end{array}$ & $\begin{array}{l}\text { Sex (percent } \\
\text { male drivers) }\end{array}$ & Ethnicity & Age & $\begin{array}{l}\text { Experience (years of holding a PCV } \\
\text { license) }\end{array}$ \\
\hline U.S. & 307 & $49.3 \%$ & $85.3 \%$ (white) & $69.6 / 6.4$ & - \\
\hline U.K. & 238 & $90.8 \%$ & $95.8 \%$ (white) & $46.7 / 10.7$ & $12.7 / 11.7$ \\
\hline Sweden & 141 & $84.8 \%$ & $\begin{array}{l}65.2 \% \text { (Swedish } \\
\text { names) }\end{array}$ & $45.6 / 9.9$ & $11.8 / 8.9$ \\
\hline Canada & 153 & $97.0 \%$ & - & $42.6 / 6.9$ & -- \\
\hline
\end{tabular}


Table 2: The means and standard deviations of the accident variables and effects on these for the error component (see Appendix 1) in the U.S. sample. Correlations between variables, and t-values (mean on the factor scores categorized by accidents dichotomised into none/some).

\begin{tabular}{|l|l|l|l|l|l|}
\hline Variable & & \multicolumn{2}{|l|}{ Self-reported, one year } & \multicolumn{2}{l|}{ State recorded, ten years } \\
\hline & & $\begin{array}{l}\text { All } \\
\text { crashes }\end{array}$ & Crashes, police present & $\begin{array}{l}\text { All } \\
\text { crashes }\end{array}$ & $\begin{array}{l}\text { Culpable } \\
\text { crashes }\end{array}$ \\
\hline $\mathrm{N}=291$ & Mean & $0.13 / 0.55$ & $0.07 / 0.32$ & $0.29 / 0.59$ & $0.20 / 0.49$ \\
\hline $\begin{array}{l}\text { Error } \\
\text { Component }\end{array}$ & Correlation & .07 & .07 & .03 & .01 \\
\hline $\mathrm{N}=291$ & $\mathrm{t}$ & $-2.38^{*}$ & -1.61 & & 1.16 \\
\hline Violation scale & Correlation & .04 & -.04 & .08 & -0.01 \\
\hline $\mathrm{N}=222$ & $\mathrm{t}$ & -0.87 & 0.57 & -1.96 & -1.29 \\
\hline
\end{tabular}

' $\mathrm{p}<.05$, one-tailed test 
Table 3: The intercorrelations (Spearman) between the accidents variables of the U.S. study. N=300.

\begin{tabular}{|l|l|l|l|}
\hline Variable & $\begin{array}{l}\text { All recorded crashes, } \\
10 \text { years }\end{array}$ & $\begin{array}{l}\text { Culpable recorded crashes, } \\
10 \text { years }\end{array}$ & $\begin{array}{l}\text { All self-reported, } 1 \\
\text { year }\end{array}$ \\
\hline $\begin{array}{l}\text { Culpable recorded crashes, } \\
10 \text { years }\end{array}$ & $.83^{* * *}$ & - & \\
\hline All self-reported, 1 year & $-.17^{* *}$ & $-.14^{*}$ & - \\
\hline $\begin{array}{l}\text { Self-reported police } \\
\text { recorded, 1 year }\end{array}$ & $-.14^{*}$ & -.11 & $.79^{* * *}$ \\
\hline
\end{tabular}

$* \mathrm{p}<.05, * * \mathrm{p}<.01, * * * \mathrm{p}<.001$, one-tailed test 
Table 4: The means and standard deviations of the (company-recorded) accident variables and effects on these for the DBQ components in the U.K. sample. Correlations between variables and t-values (mean on the component scores categorized by accidents dichotomised into none/some). Bus accidents for the total time period of employment of each driver, as shown in Table 1. No effects significant at $\mathrm{p}<.05$ (one-tailed tests).

\begin{tabular}{|c|c|c|c|c|}
\hline Variable & $\mathrm{N}=238$ & All accidents & All responsible accidents & $\begin{array}{l}\text { Solely responsible } \\
\text { accidents }\end{array}$ \\
\hline & Mean/std & $2.84 / 2.62$ & $1.43 / 1.55$ & $1.27 / 1.45$ \\
\hline \multirow[t]{2}{*}{ Component 1} & Correlation & -.04 & -.02 & -.02 \\
\hline & $\mathrm{t}$ & 1.03 & -0.95 & -0.58 \\
\hline \multirow[t]{2}{*}{ Component 2} & Correlation & .07 & .04 & .06 \\
\hline & $\mathrm{t}$ & -0.34 & -0.31 & -0.58 \\
\hline \multirow[t]{2}{*}{ Component 3} & Correlation & .04 & .00 & .01 \\
\hline & $\mathrm{t}$ & -1.27 & 1.23 & 1.11 \\
\hline \multirow{2}{*}{$\begin{array}{l}\text { Violation } \\
\text { scale }\end{array}$} & Correlation & .06 & .03 & .05 \\
\hline & $\mathrm{t}$ & -0.95 & 0.34 & 0.25 \\
\hline \multirow[t]{2}{*}{ Variable } & $\mathrm{N}=221$ & $\begin{array}{l}\text { All } \\
\text { accidents/year }\end{array}$ & $\begin{array}{l}\text { All responsible } \\
\text { accidents/year }\end{array}$ & $\begin{array}{l}\text { Solely responsible } \\
\text { accidents/year }\end{array}$ \\
\hline & Mean/std & $0.87 / .125$ & $0.48 / 0.90$ & $0.44 / 0.85$ \\
\hline Component 1 & Correlation & .00 & .00 & .01 \\
\hline Component 2 & Correlation & .11 & .05 & .06 \\
\hline Component 3 & Correlation & .04 & -.02 & -.02 \\
\hline $\begin{array}{l}\text { Violation } \\
\text { scale }\end{array}$ & Correlation & .10 & .03 & .04 \\
\hline
\end{tabular}


Table 5: The means and standard deviations of the accident variables and effects on these for the DBQ components in the Swedish sample. Correlations between variables and t-values (mean on the factor scores categorized by accidents dichotomised into none/some). All accident variables cover three years.

\begin{tabular}{|l|l|l|l|l|}
\hline Variable & & $\begin{array}{l}\text { Self-reported bus } \\
\text { accidents }(\mathrm{N}=141)\end{array}$ & $\begin{array}{l}\text { Recorded bus } \\
\text { accidents }(\mathrm{N}=141)\end{array}$ & $\begin{array}{l}\text { Self-reported car } \\
\text { accidents }(\mathrm{N}=130)\end{array}$ \\
\hline & Mean/std & $0.71 / 0.91$ & $0.79 / 1.06$ & $0.14 / 0.39$ \\
\hline \multirow{2}{*}{ Component 1 } & Correlation & $.21^{*}$ & -.05 & .13 \\
\cline { 2 - 5 } & $\mathrm{t}$ & $-2.47^{*}$ & 0.79 & $-2.05^{*}$ \\
\hline \multirow{2}{*}{ Component 2} & Correlation & -.07 & -.02 & -.06 \\
\cline { 2 - 5 } & $\mathrm{t}$ & 0.25 & 0.90 & 1.11 \\
\hline \multirow{2}{*}{$\begin{array}{l}\text { Violation } \\
\text { scale }\end{array}$} & Correlation & .00 & -.01 & .01 \\
\cline { 2 - 5 } & $\mathrm{t}$ & -1.06 & 0.44 & 0.08 \\
\hline
\end{tabular}

$* \mathrm{p}<.05$, one-tailed test 
Table 6: The means and standard deviations of the accident variables and effects on these for the DBQ component and violation scale in the Canadian sample. Correlations between variables and t-values (mean on the factor score/scale categorized by accidents/violations dichotomised into none/some). $\mathrm{N}=115$.

\begin{tabular}{|c|c|c|c|c|c|c|c|}
\hline \multirow{2}{*}{ Variable } & & \multicolumn{4}{|c|}{ Self-reported } & \multicolumn{2}{|l|}{ Recorded } \\
\hline & & $\begin{array}{l}\text { Accidents, } \\
\text { two years }\end{array}$ & $\begin{array}{l}\text { Near } \\
\text { accidents, } \\
\text { one } \\
\text { month }\end{array}$ & $\begin{array}{l}\text { Violations, } \\
\text { two years }\end{array}$ & $\begin{array}{l}\text { Accident- } \\
\text { free km, } \\
\text { two years }\end{array}$ & $\begin{array}{l}\text { Accidents, } \\
\text { total }\end{array}$ & $\begin{array}{l}\text { Accident- } \\
\text { free km }\end{array}$ \\
\hline & Mean/std & $0.09 / 0.34$ & $0.31 / 0.74$ & $0.28 / 0.54$ & $\begin{array}{l}75 \\
388 / 32 \\
722\end{array}$ & $0.55 / 0.70$ & $\begin{array}{l}491308 / 251 \\
551\end{array}$ \\
\hline \multirow{2}{*}{$\begin{array}{l}\text { Component } \\
1\end{array}$} & Correlation & .10 & .11 & .18 & -.03 & -.02 & -.12 \\
\hline & $\mathrm{t}$ & -1.26 & -1.72 & -1.86 & - & 0.44 & - \\
\hline \multirow{2}{*}{$\begin{array}{l}\text { Violation } \\
\text { scale }\end{array}$} & Correlation & .16 & .04 & $.19 *$ & -.13 & .02 & -.02 \\
\hline & $\mathrm{t}$ & $-2.19 *$ & -0.63 & $-1.99 *$ & - & -0.29 & - \\
\hline
\end{tabular}

$* \mathrm{p}<.05$, one-tailed test 